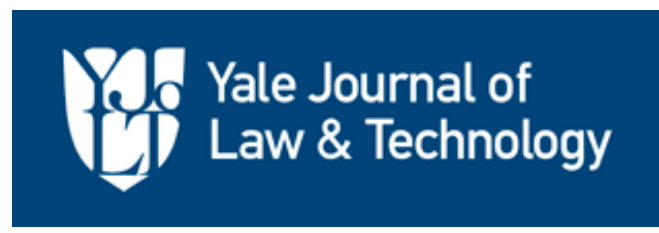
HOME

\title{
STRICT LIABILITY AND 3D-PRINTED MEDICAL DEVICES
}

By: Eric Lindenfeld \& Jasper L. Tran. December 11, 2015.

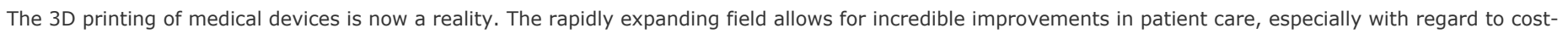

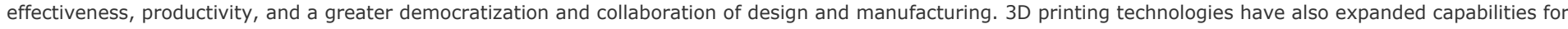

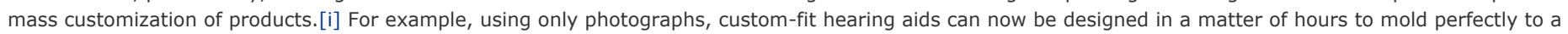

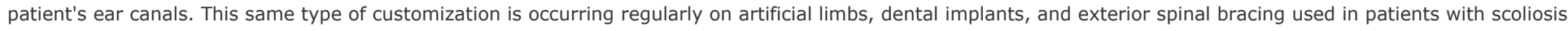

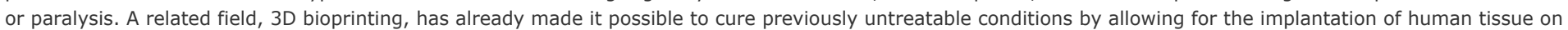

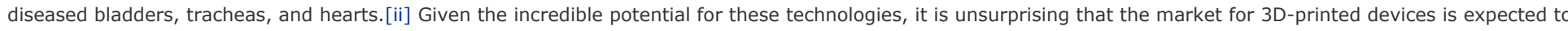
be worth $\$ 2.16$ billion by 2020 , with the bio printing market worth nearly $\$ 6$ billion.[iii]

\section{The Problem}

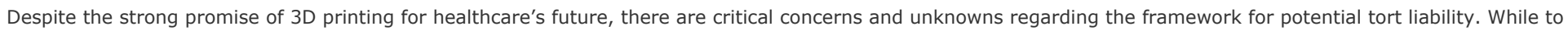

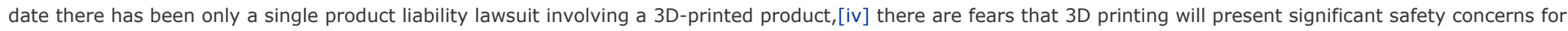

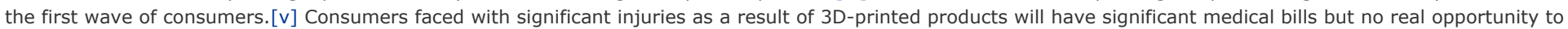

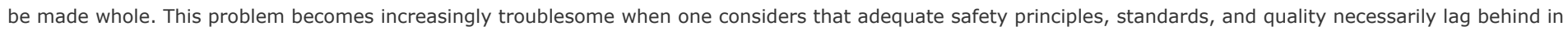

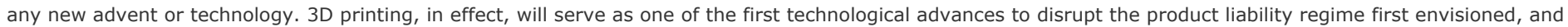
eventually instituted, by Justice Roger Traynor of the California Supreme Court.[vi]

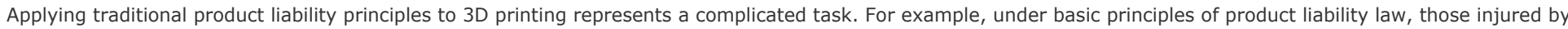

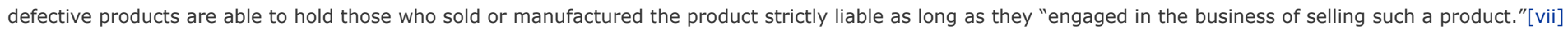

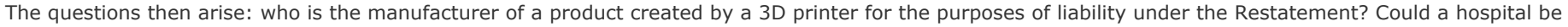

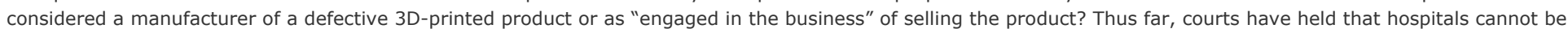

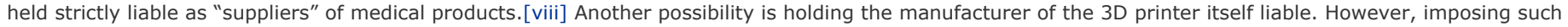
excessive liability on the manufacturer for any future equipment the 3D printer may make would be inconsistent with prior case law dealing with analogous

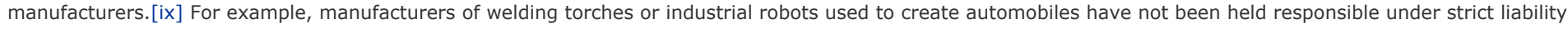

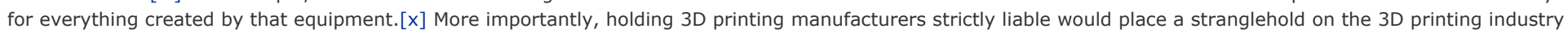

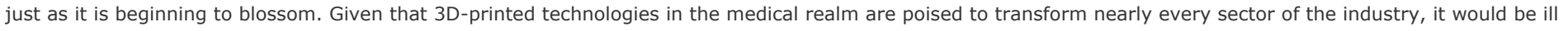

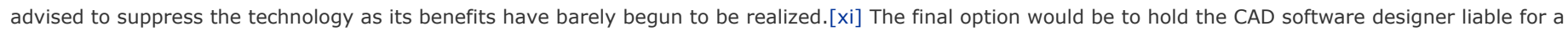

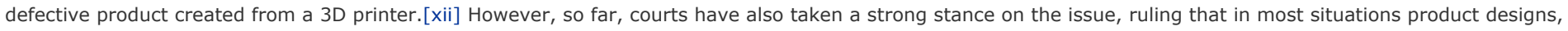
especially software codes, are not "products" as contemplated by the Second Restatement. [xiii]

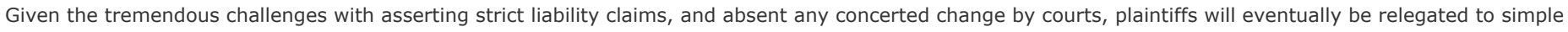

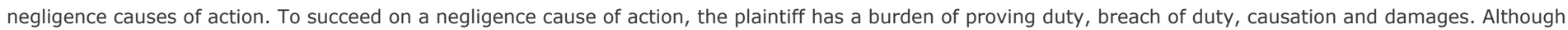

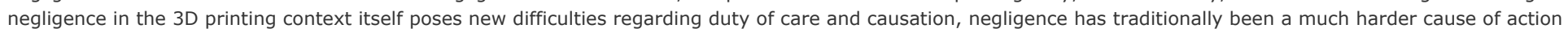
to prove.

\section{The Solution}

To avoid such an undesirable result, it is imperative that courts make a concerted effort to redefine the boundaries of product liability law to account for new

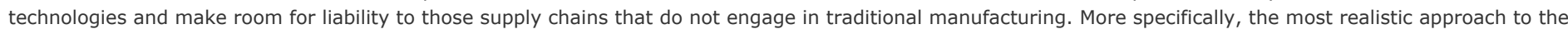
problem would be for courts to uniformlyhold CAD software designers responsible for the defects related to design of the 3D-printed products.

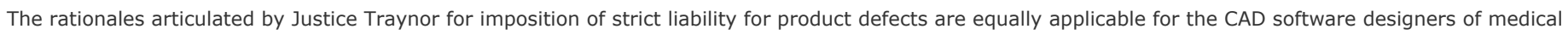

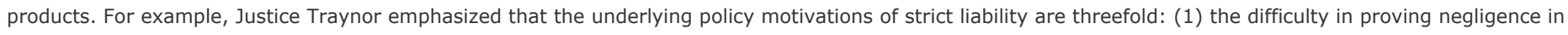

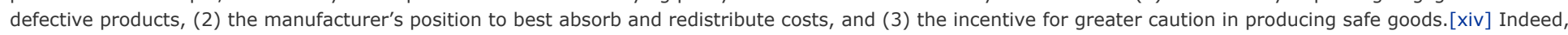

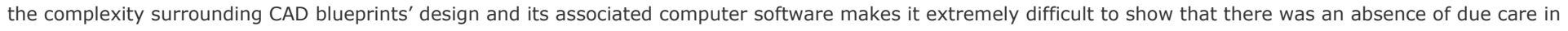

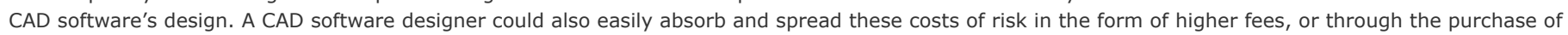

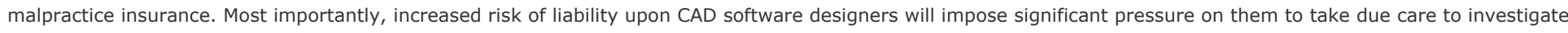

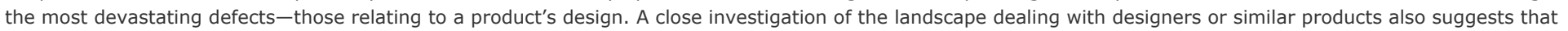

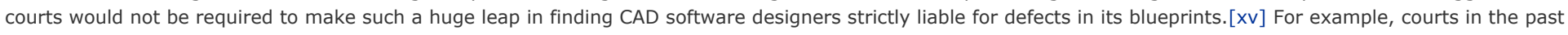
have been willing to find that information contained in aeronautical[xvi] and navigational charts[xvii] are products under strict liability principles.

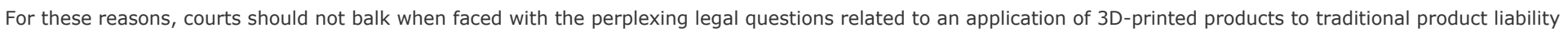

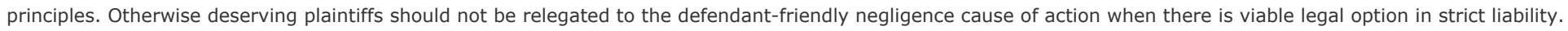

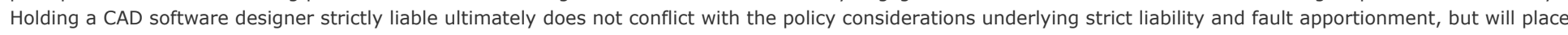
the burden upon those who are in the best position to prevent the injury in the first place.

[i] See generally Jasper L. Tran, The Law \& 3D Printing, 31 J. Info. Tech. \& Privacy L. 505 (2015).

[ii] See Jasper L. Tran, To Bioprint or Not to Bioprint, 17 N.C. J.L. \& Tech. 123,138 \& n.13 (2015).

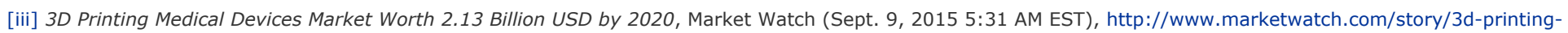

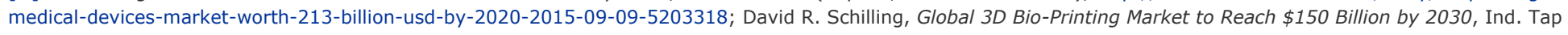


(June 30, 2015), http://www.industrytap.com/global-3d-bio-printing-market-reach-150-billi... ("According to a number of research reports, the global 3D bio-printing market in the healthcare industry is set to grow at a compound annual growth rate (CAGR) of nearly $15 \%$ to about $\$ 6$ billion by $2020 . "$ ).

[iv] Buckley v. Align Technology, Inc., No. 5:13-cv-02812-EJD, 2015 U.S. Dist. LEXIS 133388 (N.D. Cal. Sept 29, 2015).

[v] Tran, To Bioprint, supra note 2, at 141-46.

[vi] Escola v. Coca Cola Bottling Co., 150 P.2d 436, 441 (Cal. 1944) (Traynor, J., concurring) ("Those who suffer injury from defective products are unprepared to meet its consequences. The cost of an injury and the loss of time or health may be an overwhelming misfortune to the person injured, and a needless one, for the risk of injury can be insured by the manufacturer and distributed among the public as a cost of doing business.").

[vii] Restatement (Second) of Torts, Products Liability § 402 (2015).

[viii] Restatement (Third) of Torts, Products Liability $\S 20$ (2015) ("[I]n a strong majority of jurisdictions, hospitals are held not to be sellers of products they supply in conjunction with the provision of medical care, regardless of the circumstances."); see also id. at § 20 , cmt. d ("[I]n a strong majority of jurisdictions, hospitals are held not to be sellers of products they supply in conjunction with the provision of medical care, regardless of the circumstances.").

[ix] James A. Henderson, Jr., Echoes of Enterprise Liability in Product Design and Marketing Litigation, 87 Cornell L. Rev. 958, 973 (2002) ("Courts have rejected attempts by plaintiffs to extend strict liability to commercial enterprises that supply machinery, vehicles, and other equipment to those who themselves engage in activities deemed abnormally dangerous."); see also Cropper v. Rego Distribution Ctr., Inc., 542 F. Supp. 1142, 1147-49 (D. Del. 1982) (finding no strict liability for the manufacturer of machinery utilized to store and transport hazardous chemicals even though the purchaser of the machinery utilized it as part of an abnormally dangerous activity); Cavan v. Gen. Motors Corp., 571 P.2d 1249, 1251 (Or. 1977) ("Historically, the strict liability rule ... is applied when an activity creates an abnormally dangerous condition, or by its nature presents extraordinary risk of harm .... It has no applicability in a products case.").

[x] See Some Ideas About 3D Printing, Drug \& Device L. Blog (Feb. 5, 2015), http://druganddevicelaw.blogspot.com/2015/02/some-ideas-about-3d-printing.html ("Imposing strict liability on the printer manufacturer for any product the printer could be configured to produce would be like imposing crashworthiness liability on the makers of the industrial robots used to make automobiles, or more generally on makers of a welding torches or plastic extrusion molders for everything that such equipment might be used to make.").

[xi] Spencer Thompson, 3D Printing Is Coming - so Let's Not Strangle the Industry at Birth, The Guardian (Oct. 16, 2012 8:00 EDT), http://www.theguardian.com/commentisfree/2012/oct/16/get-ready-for-3d-printing.

[xii] For a discussion of CAD software, see generally Kyle Dolinsky, CAD's Cradle: Untangling Copyrightability, Derivative Works, and Fair Use in 3D Printing, 71 Wash. \& Lee L. Rev. 591, 600 (2014).

[xiii] See, e.g., In re Minnesota Breast Implant Litig., 36 F. Supp. 2d 863, 872 (D. Minn. 1998) (ruling that "if 3M played no role in the manufacture or sale of Plaintiffs' breast implants, 3M cannot be strictly liable"); Christian v. Minnesota Mining \& Manufacturing Co., 126 F. Supp.2d 951, 958 (D. Md. 2001) (finding developer of product, that no longer manufactured it, not strictly liable).

[xiv] See, e.g., Greenman v. Yuba Power Prods., Inc., 377 P.2d 897 (Cal. 1963); see also Brooks v. Beech Aircraft Corp., 902 P.2d 54, 56 (N.M. 1995 ) (discussing four primary policies supporting imposition of strict products liability).

[xv] Cf. Patrick T. Miyaki, Comment, Computer Software Defects: Should Computer Software Manufacturers Be Held Strictly Liable for Computer Software Defects?, 8 Santa Clara Computer \& High Tech. L.J. 121, 122-23 (1992) (arguing for strict liability in computer software defects).

[xvi] E.g., Fluor Corp. v. Jeppesen \& Co., 170 Cal. App. 3d 468, 474 (Ct. App. 1985) (finding charts as "products" for purposes of strict liability); Brockelsby v. U.S., 767 F.2d 1288, 1295 (9th Cir. 1985) (finding an aeronautical chart as "a defective product for purposes of analysis under section 402A").

[xvii] E.g., Saloomey v. Jeppesen \& Co., 707 F.2d 671, 676-77 (2d Cir. 1983) (holding that navigational charts were products under section 402A, and that mass production and marketing of charts required that the defendant bear the costs of accidents proximately caused by the charts).

\author{
Recent Posts \\ Finding a Proxy for Net Neutrality \\ Dolly The Sheep: A Cautionary \\ Tale \\ Law vs. Regulations in the \\ Common Rule
}

RELATED LINKS

Yale Law School Information Society Project MFIA Startup Practicum Knight Law \& Media Program

Yale Journal of Law \& Technology 